Gut, 1966, 7, 317

\title{
A histochemical study on the role of lysosomal enzymes in idiopathic steatorrhoea before and during a gluten-free diet
}

\author{
E. O. RIECKEN, ${ }^{1}$ J. S. STEWART, ${ }^{2}$ C. C. BOOTH, AND A. G. E. PEARSE \\ From the Departments of Pathology and Medicine, Hammersmith Hospital and \\ Postgraduate Medical School, London
}

EDITORIAL SYNOPSIS The small intestinal epithelium in idiopathic steatorrhoea was studied histochemically in patients before and during treatment with a gluten-free diet. Rapid recovery of nearly all the enzymes studied started within a week of treatment, even in the most severely damaged mucosa.

Special attention was paid to the lysosomal enzymes, which act as markers of the lysosomal organelles. Enzyme activity was both decreased and abnormally diffuse in every patient with idiopathic steatorrhoea before treatment, suggesting damage to the lysosomal membrane with consequent uncontrolled release of highly destructive enzymes leading to cellular autodigestion. The generalized decrease observed in enzyme activity is probably due to this damaging action of the lysosomal enzymes which may well also account for the breakdown of the cyto-architecture. Although decreased enzyme activity is the dominant histochemical feature, there is evidence of a compensatory increase in enzyme production, as shown in particular by the appearance of acid phosphatase activity in the Golgi apparatus.

The cellular disorder of the small intestine in idiopathic steatorrhoea was first investigated histochemically in detail by Padykula, Strauss, Ladman, and Gardner (1961), who described characteristic changes in the histochemical pattern of the small intestinal mucosa. They demonstrated a lower germinative crypt zone twice as long as the normal crypt in which enzymes were virtually normal, above this a short middle zone with absorptive cells histochemically similar to the epithelium of thenormal villus, and, finally, an upper zone of surface cells which showed gross histochemical abnormalities. These changes were associated with an increased mitotic rate in the crypt zone together with disturbances of the structure of the surface cells.

More recent investigations (Plosscowe, Berg and Segal, 1963; Spiro, Filipe, Stewart, Booth, and Pearse, 1964; Fric and Lojda, 1964; Samloff, Davis, and Schenk, 1965) have in general confirmed these findings. The reported changes in enzyme activity,

${ }^{1}$ This work was supported partly by the Adolf-Schmidtmann Stiftung, University of Marburg, Germany, and partly by a British Council scholarship. Present address: Medizinische Universitätsklinik, Marburg/Lahn, Germany.

${ }^{2}$ This work was done during the tenure of a T. K. Stubbins research fellowship of the Royal College of Physicians of London. however, are strikingly variable and the mucosal zones described by Padykula et al.(1961) as characteristic of idiopathic steatorrhoea have not always been observed (Spiro et al., 1964).

The present investigation concerns the histochemical changes in the small intestinal mucosa of patients with idiopathic steatorrhoea before and during treatment with a gluten-free diet. Special attention is drawn to the changes affecting the lysosomes, which may prove to be fundamental to the understanding of the pathogenesis of the mucosal lesion.

\section{MATERIALS AND METHODS}

Thirty-three small intestinal biopsies were taken from 23 subjects, 12 of whom suffered from idiopathic steatorrhoea; 10 were repeat biopsies, including six from one patient during treatment with a gluten-free diet. The specimens were obtained in the early afternoon, and the patients had been starved since the previous evening. The site chosen for biopsy was the upper part of the jejunum just beyond the ligament of Treitz in all but one instance, when the specimen was taken from the fourth part of the duodenum. The Crosby intestinal biopsy capsule (Crosby and Kugler, 1957) was used and the position of the capsule was confirmed radiologically in every case. Control 
biopsies, 11 in all, were obtained from a healthy volunteer (physician) and from patients with post-gastrectomy states and iron- and folic-acid deficiency anaemia not due to malabsorption. The tissue was rapidly removed from the capsule and divided into four pieces for processing in four different ways:-

1 Tissue, less than $1 \mathrm{~mm}^{3}$ large, was fixed in buffered $\mathrm{OsO}_{4}(1 \%)$ at $p \mathrm{H} 7 \cdot 3$ for one hour at $4{ }^{\circ} \mathrm{C}$., dehydrated, and embedded in epoxy resin (araldite).

2 Tissue was fixed for 18 hours in cold phosphatebuffered formalin (4\%), of neutral $p \mathrm{H}$, according to the method of Sabatini, Bensch, and Barrnett (1963), for histochemical and combined electron-histochemical techniques; it was then stored in ice-cold phosphatebuffered (0.1M.) sucrose (0.22M.) until used for electron microscopy. For histochemical investigation it was stored for two days only in this solution and was then embedded in a block of fresh tissue, quenched, and stored in airtight plastic bags at $-70^{\circ} \mathrm{C}$. until use.

3 Tissue was quenched immediately in liquid nitrogen after embedding in fresh liver tissue on a piece of cork. It was then stored in airtight plastic bags at $-70^{\circ} \mathrm{C}$.

4 Tissue was placed in a flat dish containing formalin $(15 \%)$ for immediate study under the dissecting microscope (Holmes, Hourihane, and Booth, 1961), photography (Brackenbury and Stewart, 1963), and subsequent routine histology. The height of epithelial surface cells was measured using an eyepiece micrometer as described by Shiner and Doniach (1960).

\section{TECHNIQUES FOR MEMBRANE ENZYMES}

Non-specific alkaline phosphatase (Burstone, 1958) was estimated using $a$-naphthol-ASMX-phosphate and Fast Red TR (4-chloro-o-toluidine) as a coupler and also the Gomori technique (1952) using sodium- $\beta$-glycerophosphate as substrate. L-phenylalanine served as inhibitor (0.05M.).

Adenosine triphosphatase (ATP-ase) was estimated by the method of Wachstein and Meisel (1957).

Leucine aminopeptidase was estimated according to the method of Nachlas, Crawford, and Seligman (1957) using L-leucyl-4-methoxy- $\beta$-naphthylamide and Fast Blue B (0-dianisidine) as coupling agent. Formaldehyde prefixed and cold acetone post-fixed sections were used.

\section{TECHNIQUES FOR LYSOSOMAL ENZYMES}

Non-specific acid phosphatase (Barka and Anderson, 1962) using $\alpha$-naphthol-ASBI-phosphate as substrate and hexazonium-pararosanilin as coupler and also by the Gomori technique (1952), using sodium- $\beta$-glycerophosphate as substrate.

$\beta$-glucuronidase according to Pugh and Walker (1961) using $a$-naphthol-ASLC-glucuronide as substrate and hexazonium-pararosanilin as coupling agent.

Cathepsin-like $E 600$ resistant esterase according to Hess and Pearse (1958) using the indoxyl acetate-esterase technique (Holt, 1958), and 4-chloro-5-bromo-indoxyl-oacetyl as substrate and the thiolacetic acid esterase technique (Barrnett, 1962); E 600 concentration $10^{-3} \mathrm{M}$.

Glucosaminidase according to Pugh and Walker (1958) using $\alpha$-naphthyl acetyl- $\beta$-D-glucosaminide as substrate.
Formaldehyde prefixed and cold acetone postfixed sections were used.

\section{TECHNIQUES FOR MITOCHONDRIAL ENZYMES}

Succinic dehydrogenase according to Nachlas, Tsou, Souza, Cheng, and Seligman (1957).

Nicotine adenine dinucleotide (NAD $\mathrm{H}$ ) and nicotine adenine dinucleotide phosphate (NADP H)_-diaphorases according to Scarpelli, Hess, and Pearse (1958).

Monoamine oxidase according to Glenner, Burtner, and Brown (1957), TNBT was used as an electronacceptor in all the methods mentioned in this section. Unfixed sections were used.

\section{TECHNIQUES FOR MICROSOMAL ENZYMES}

Glucose-6-phosphatase according to Wachstein and Meisel (1956).

Non-specific esterase according to Holt (1958) and Barrnett (1962) as described for the estimation of $\beta$ glucuronidase above. Unfixed cryostat-cut sections were used.

\section{TECHNIQUE FOR GOLGI (LAMELLAR) ENZYME}

Thiamine pyrophosphatase according to Novikoff and Goldfischer (1961). Formaldehyde prefixed and cold formal-calcium postfixed sections were used. Omission of substrate from the incubation medium and enzyme inactivation by heat were used to check the specificity of the enzyme reaction.

\section{RESULTS IN CONTROL SUBJECTS}

MEMBRANE ENZYMES All three enzymes demonstrated were strongly positive in the brush border (Figs. 1a and 2a). Non-specific alkaline phosphatase and ATP-ase showed precise localization. The very fine crystalline reaction product of the Burstone reaction became coarser on extension of the incubation period $\left(30\right.$ minutes at $18^{\circ} \mathrm{C}$.) and appeared distinct from the brush border, in the apical part of the cell. Alkaline phosphatase was also seen in the supranuclear zone, marking the Golgi apparatus, when the Gomori technique was used. The Burstone method, however, did not stain this site, apparently because of substrate protection. Inhibition with L-phenylalanine abolished alkaline phosphatase activity when sodium-glycerophosphate served as substrate (Gomori technique), but it only partly diminished this activity when $\alpha$-naphthol-ASBIphosphate was used (Burstone technique). Activity towards ATP was partly inhibited.

Leucine aminopeptidase was less distinctly localized than the other two enzymes, except in the brush border. This is interesting because there is evidence from recent investigations (Sylvén and BoisSvensson, 1964) that this enzyme may be of lysosomal origin.

All three enzymes decreased sharply in the cells at the junction of villus and crypt; alkaline phosphatase 


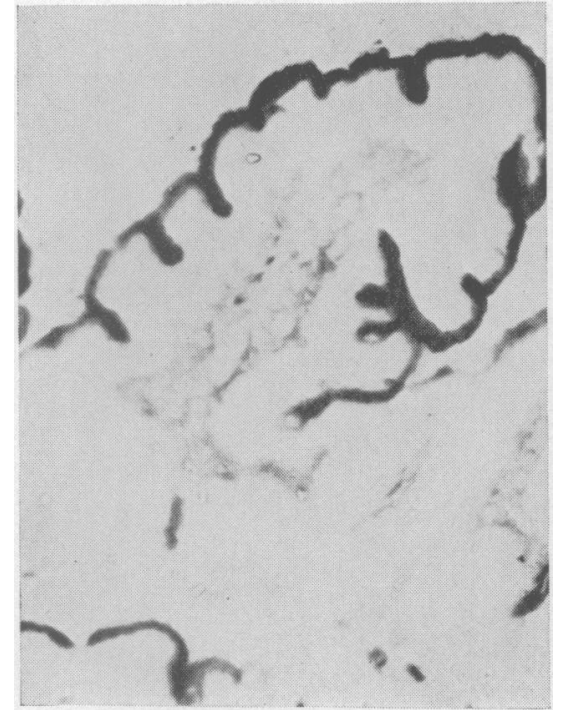

FIG. 1a

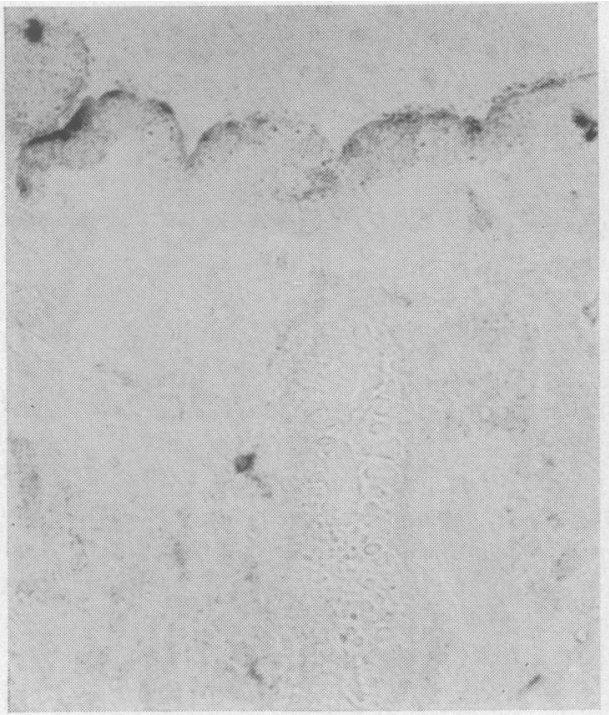

FIG. 1c

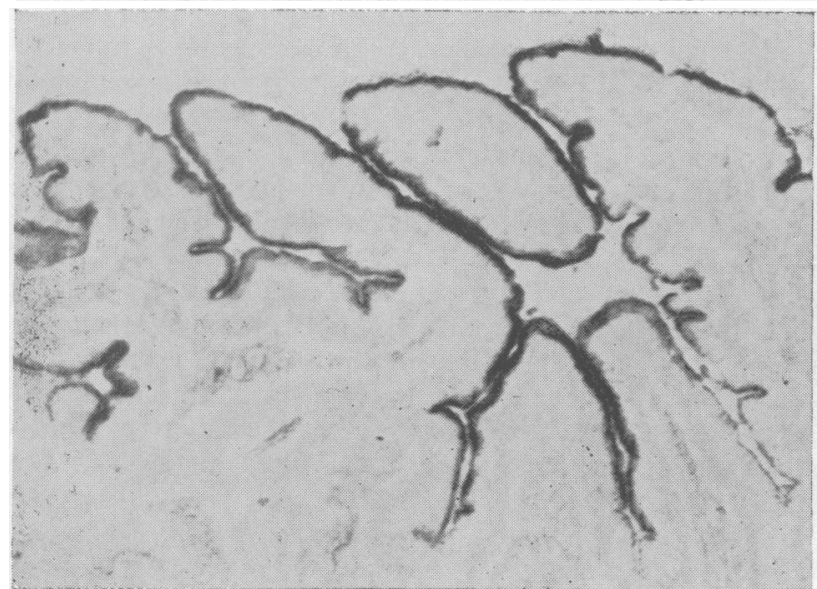

FIG. 1e

FIG. 1 b

FIG. 1d
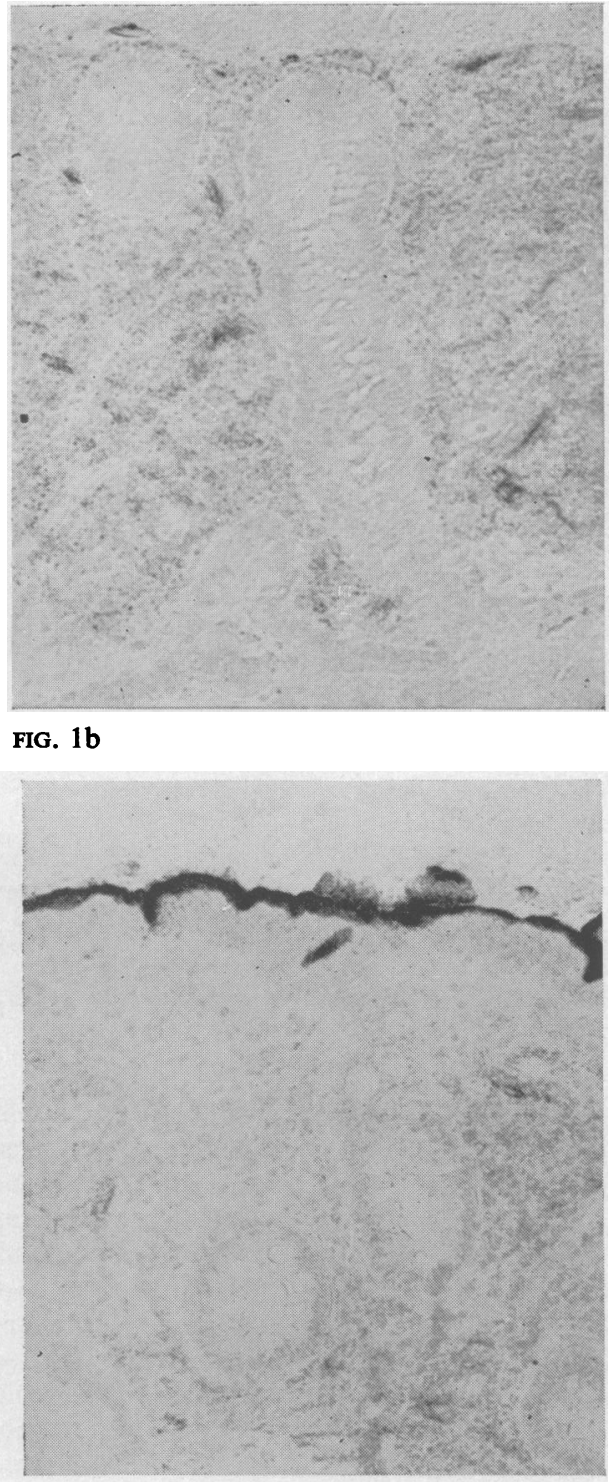

FIG. 1c and d. Jejunum. Alkaline phosphatase. Sections obtained from the same patient as in Fig. 1b, one and four weeks after beginning a gluten-free diet. Nearly normal activity is seen at four weeks although the mucosa is still flat (dissecting microscope appearance; flat with mosaic). $\times 160$.

FIG. 1e. Jejunum. Alkaline phosphatase. Almost complete return to normal activity in a patient after 22 months on a gluten-free diet. $\times 160$.
FIG. 1a. Normal jejunum. Alkaline the absorp This section was simulbated shown in Figures 16 to 1 e. $\times 160$.

FIG. 1b. Jejunum in alkaline phosphatase activity is completely absent from the brush border. A slight diffuse lamina propria. $\times 160$ phosphatase. The fined to the brush the lamina propria. colour reaction is still 
FIG. 2a. Normal jejunum. L.A.P. control, incubated simultaneously with sections shown in Figures $2 b$ and $2 c$. The activity is localized in the brush border. No reaction is seen in the lamina propria. $\times 160$.

FIG. 2b. Jejunum in untreated idiopathic steatorrhoea. L.A.P. activity is largely abolished. $\times 160$.

FIG. 2c. Jejunum of the same patient as shown in Fig. $2 b$ four weeks after treatment. L.A.P. marked increase of activity $\times 160$.

and leucine aminopeptidase often vanished completely in the upper third of the crypt while ATP-ase was always present in all cells. Paneth cells seemed to have little if any activity.

Macrophages, leucocytes, and vessels of the lamina propria gave a positive reaction for alkaline phosphatase and ATP-ase; smooth muscle fibres were also ATP-ase positive. No reaction was obtained with the leucine aminopeptidase technique.

LYSOSOMAL ENZYMES The activity of this group was confined to a narrow zone of well-defined granules varying in size and shape, aligned beneath the brush border (Figs. 3a, 4a, and 5a). A more scattered distribution reaching from the apex of the cell to the Golgi area was found in only one biopsy, but even in this specimen most of the granules were found in the upper zone. The average number of bodies counted in one cell, using sections $4 \mu$ thick, lay between four and six but there were cells containing only one and others up to ten. Acid phosphatase activity occurred only rarely in the Golgi zone in the surface epithelium. In the goblet cells, however, this localization was quite common.

Crypt activity was much reduced and it was now confined to very small and pale looking granules which were scattered loosely throughout the apical cytoplasm of the cell. Paneth cells contained all the enzymes of this group.

Equally good results were obtained with formalcalcium and buffered formaldehyde prefixation. The individual lysosomal granules were demonstrable with the techniques for acid phosphatase, $\beta$ glucuronidase, and lysosomal esterase. This last enzyme showed the individual granules only when demonstrated by the Barrnett method. The granules of one cell fused into a single spot when they were demonstrated by the indoxylacetate esterase method (Fig. 4a).

Glucosaminidase localization was histological rather than cytological. An attempt was made to demonstrate this enzyme more precisely, with substituted naphthol-AS-phosphate and hexazoniumpararosanilin as coupling agent. This failed, apparently because of substrate protection, since in more active tissues excellent lysosomal localization can be achieved (Wächtler and Pearse, 1966). Greatest activity was seen with non-specific acid phosphatase, which was therefore the best marker enzyme of this group; both techniques applied gave clear-cut localization but the Barka and Anderson technique was better for the detection of extralysosomal activity, as seen after damage to the lysosomal membrane. Post-fixation with cold acetone 


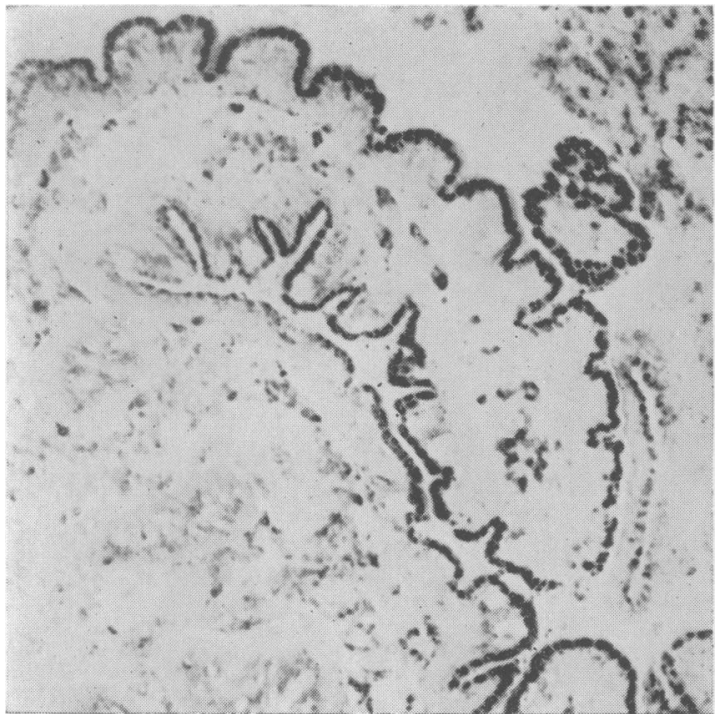

FIG. 3a.

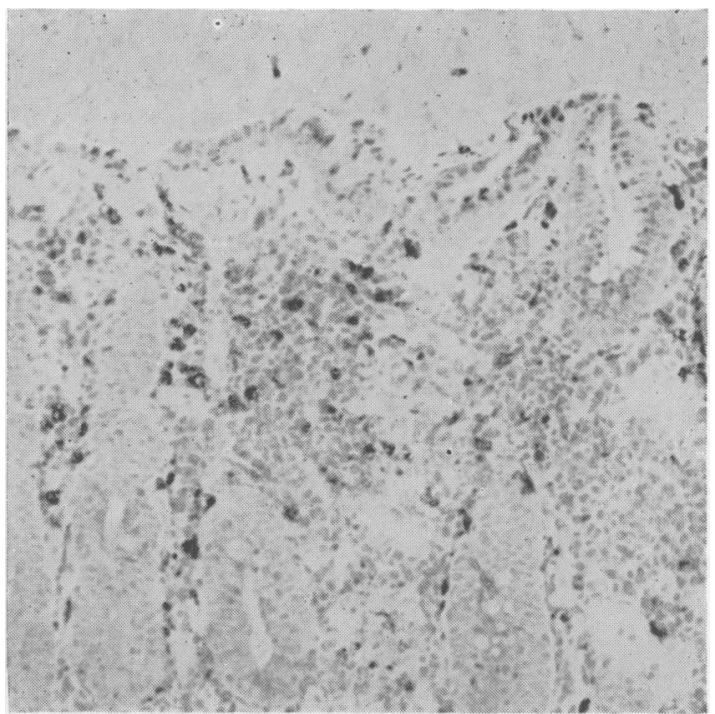

FIG. 3 b.

FIG. 3a. Normal jejunum. Acid phosphatase. The activity is confined to lysosomal bodies beneath the brush border of the absorptive epithelium and to macrophages of the lamina propria: incubated simultaneously with the sections shown in Figures $3 b$ to $3 f$. $\times 160$.

FIG. 3b. Jejunum in untreated idiopathic steatorrhoea. Acid phosphatase. Flat mucosa and severe reduction in height of surface cells associated with almost complete loss of activity and lysosomes. $\times 160$.

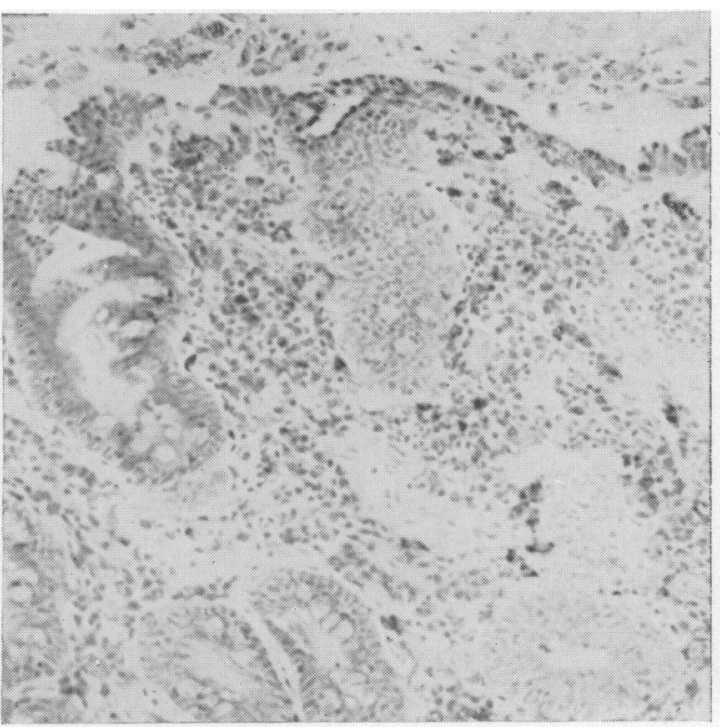

FIG. 3c.

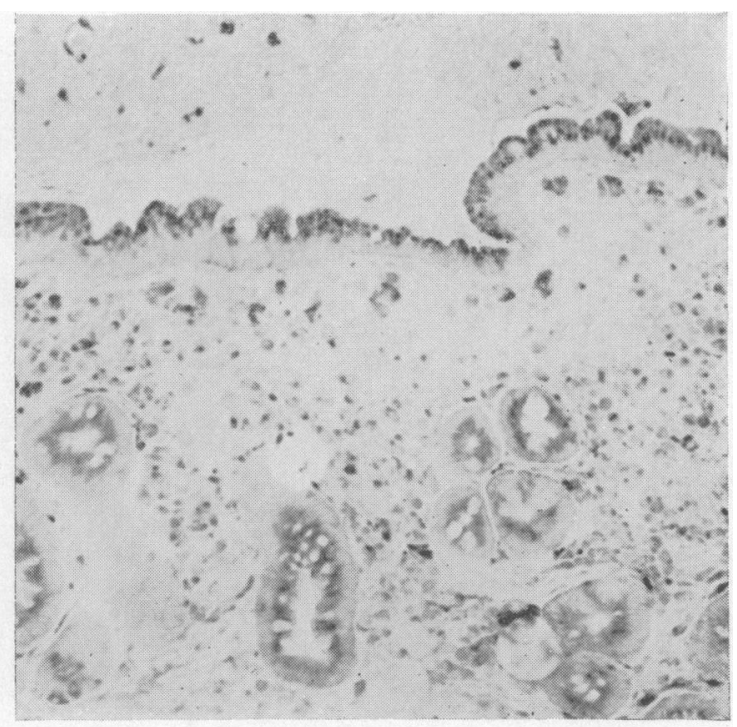

FIG. 3d.

FIG. 3c and d. Jejunum of the same patient as in Fig. $3 b$ four and 12 weeks after beginning a gluten-free diet. Striking increase of acid phosphatase activity with reappearance of typical lysosomal granules beneath the brush border. A second zone of activity appears in the surface epithelium marking the Golgi zone. $\times 160$. 


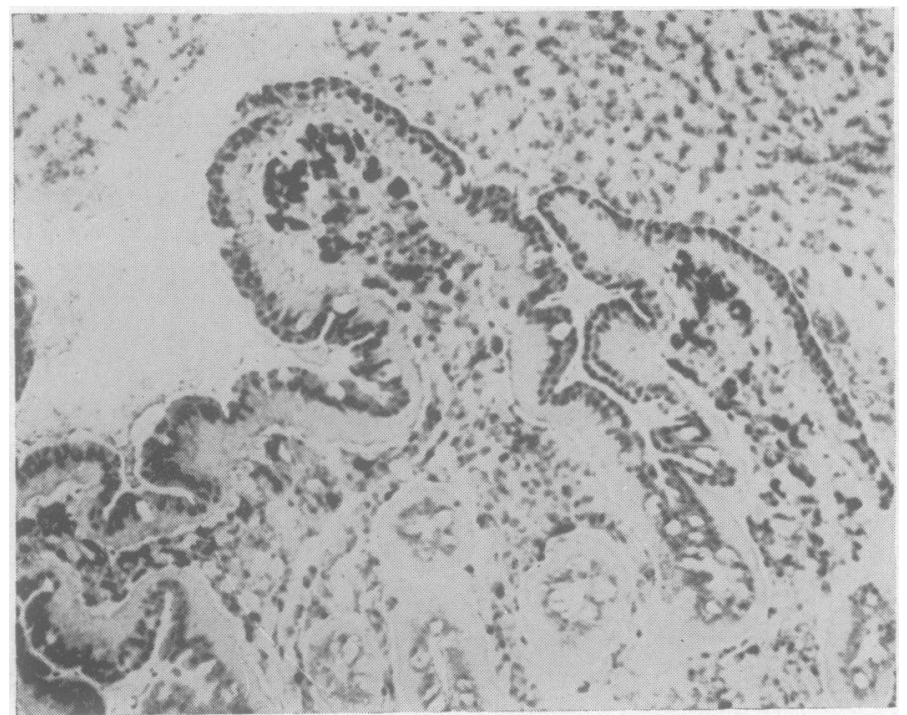

FIG. 3e. Jejunum of a patient with idiopathic steatorrhoea 27 months after treatment with gluten-free diet. Acid phosphatase. Marked activity in the Golgi zone indicates enhanced enzyme production. Note also the activation of the macrophages in the lamina propria. $\times 160$.

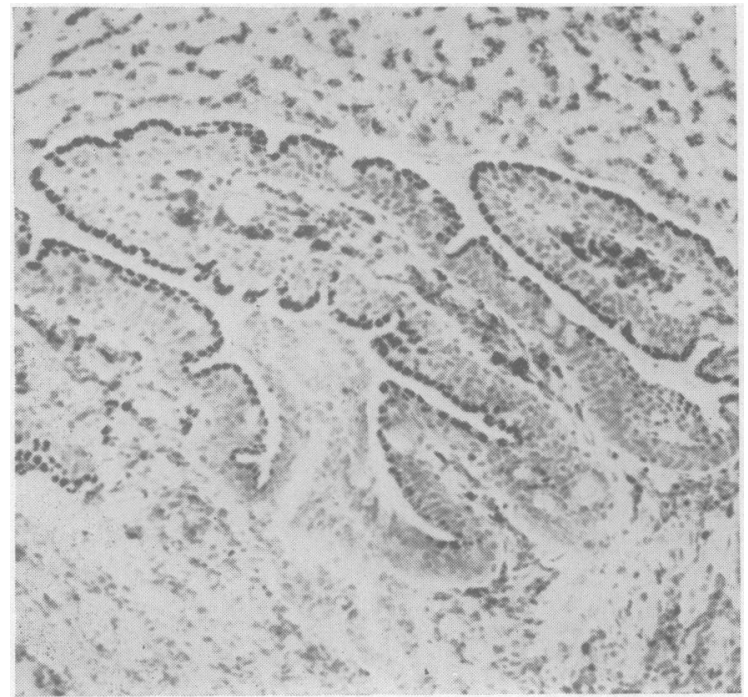

FIG. 3f. Jejunum in idiopathic steatorrhoea after 22 months on a gluten-free diet showing return to normal of acid phosphatase activity and lysosomes in surface epithelium and macrophages. $\times 160$.

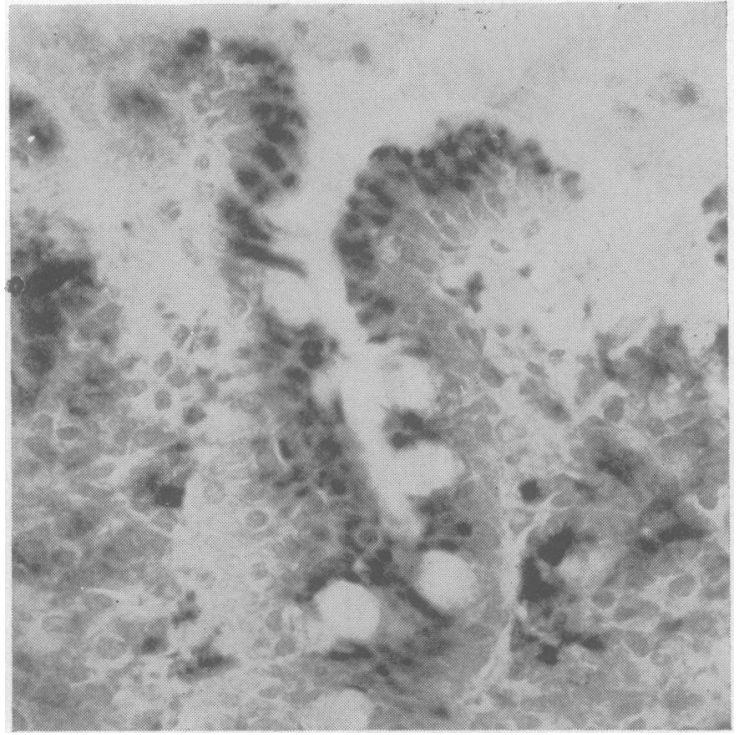

FIG. 3g. Jejunum. Untreated idiopathic steatorrhoea. Acid phosphatase. The relatively strong activity in the upper part of the elongated crypt (identical with the second zone of Padykula) is associated with activity in the Golgi zone indicating enhanced production of enzymes. $\times 370$. 


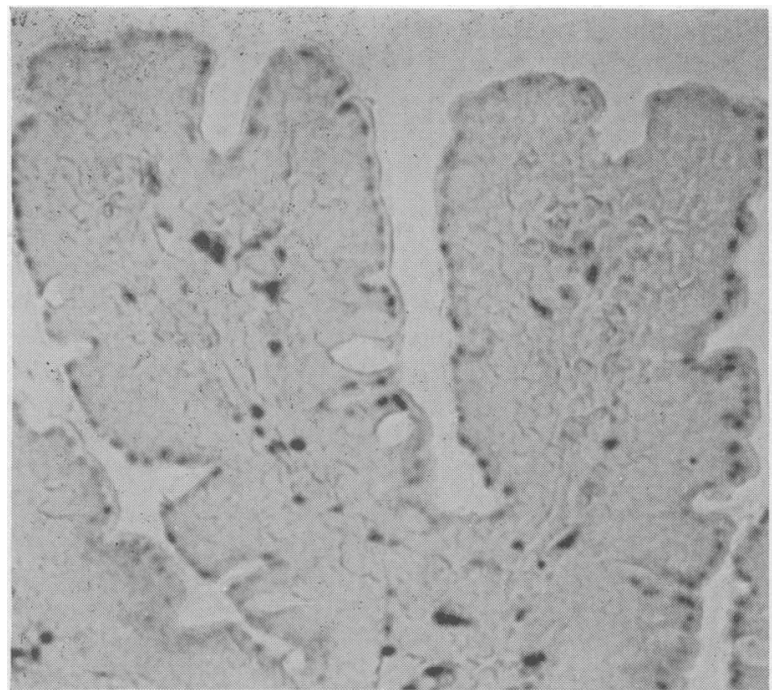

FIG. $4 a$.

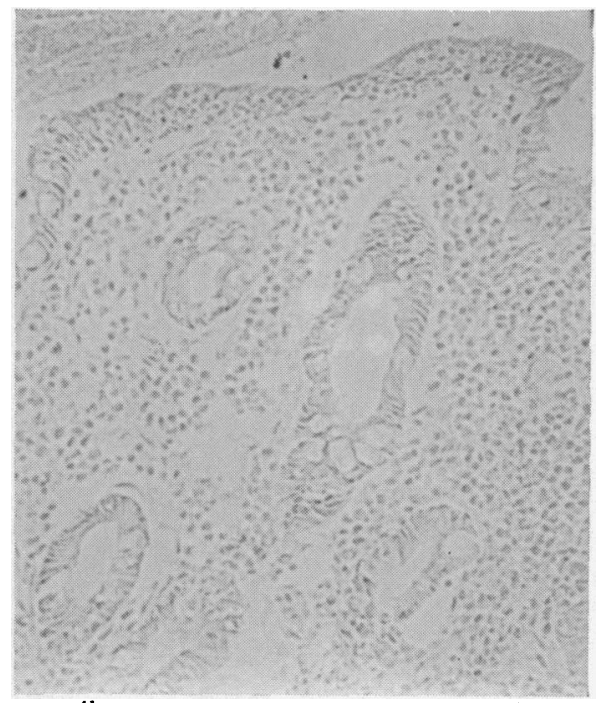

FIG. 4b.

FIG. 4a. Jejunum. E600-resistant esterase (Hess and Pearse). Normal lysosomal activity in a patient after 22 months on a gluten-free diet. The site of reaction is identical with localization of acid phosphatase (compare with Fig. $3 a$ ). $\times 310$.

FIG. 4b. Jejunum. E 600-resistant esterase in untreated idiopathic steatorrhoea: incubated simultaneously with the section shown in Figure 4a. Complete loss of activity. $\times 160$.

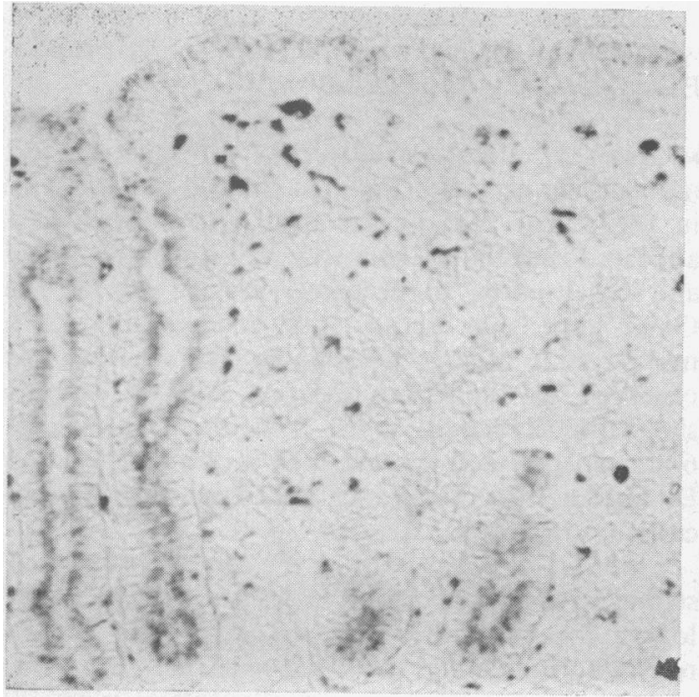

FIG. 4c.

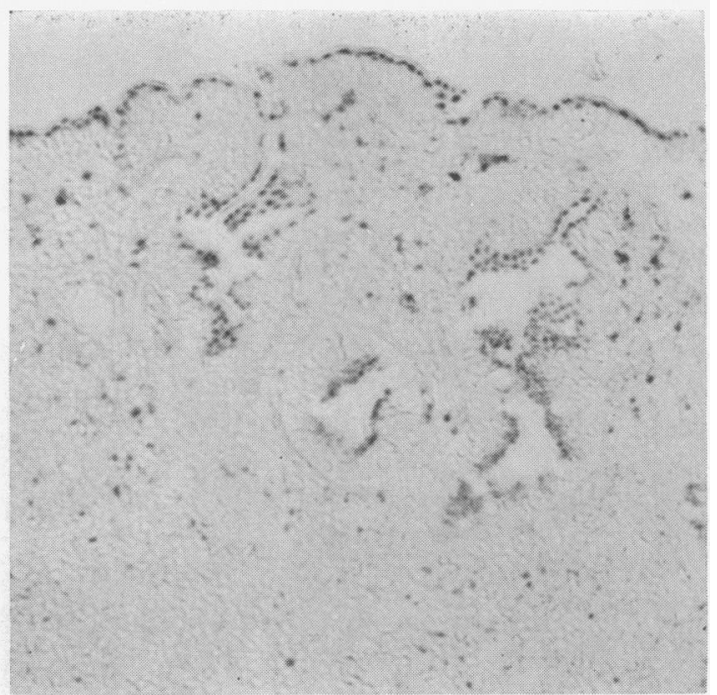

FIG. 4d.

FIG. 4c and d. Jejunum. Lysosomal esterase (Holt technique) in a patient with idiopathic steatorrhoea before and four weeks after the start of a gluten-free diet. Simple formal calcium fixation was required to demonstrate the increase of lysosomal activity after treatment. On inhibition with E 600 both sections showed almost complete failure to take up any stain. 


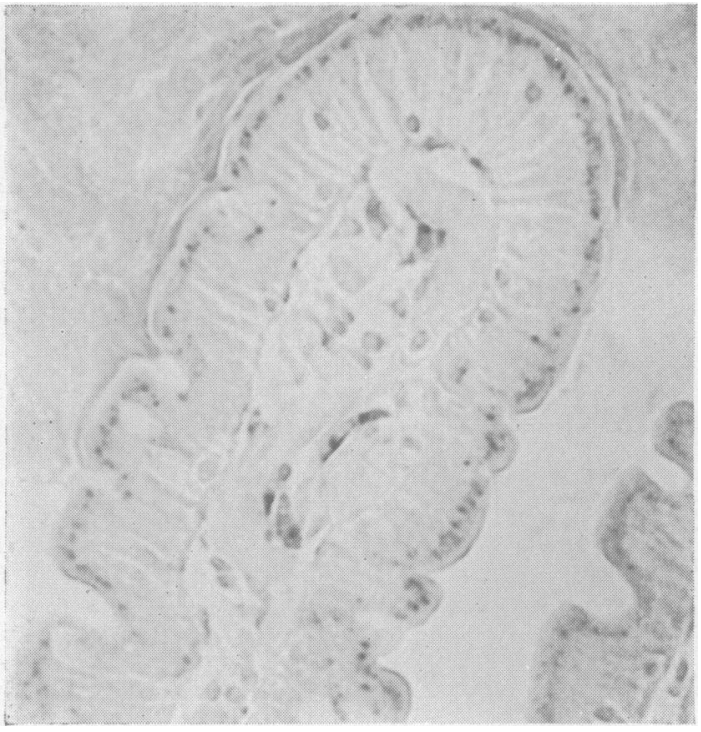

FIG. 5a. Normal jejunum. $\beta$-glucuronidase. Lysosomal activity in the typical site. Compare with Figures $3 a$ and 4a. $\times 320$.

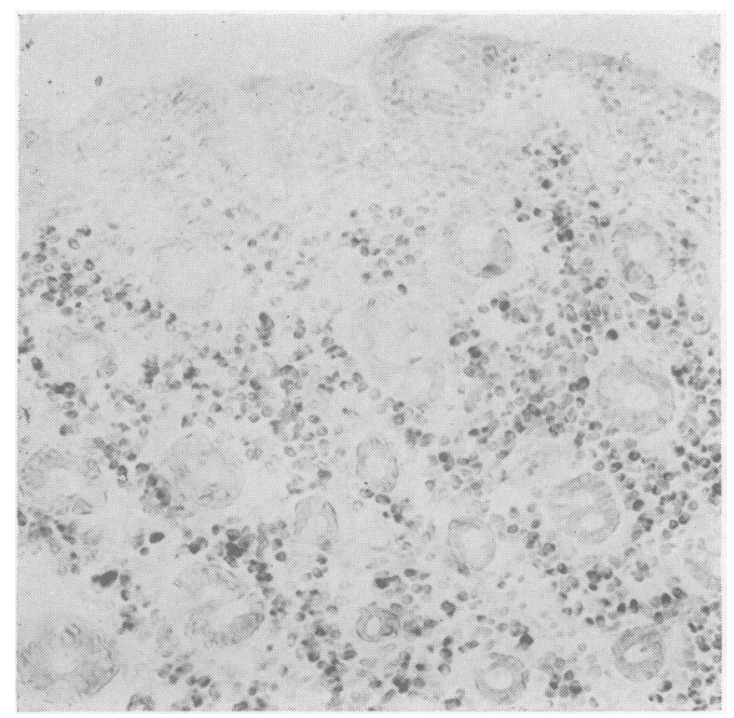

FIG. 5b. Jejunum. $\beta$-glucuronidase. Untreated idiopathic steatorrhoea: incubated simultaneously with section shown in Figure 5a. Complete loss of activity in the surface epithelium but increased activity in the macrophages of the lamina propria. $\times 160$. preserved granular activity strikingly, although some diffusion occurred. Inhibition of acid phosphatase activity with sodium fluoride abolished the reaction completely. Staining of the brush border, seen on extension of the incubation time, was resistant to inhibition.

MITOCHONDRIAL ENZYMES Oxido-reductive enzymes are predominantly localized in mitochondria as shown by biochemical investigation. The diformazan deposits of this enzyme group seemed to be arranged in three zones throughout the absorptive epithelial cells (Fig. 6a). The broadest zone was spread in the apical part of the cell between the unstained brush border and the lightly stained Golgi zone, the second between the Golgi zone and upper rim of the nucleus, and the third beneath the nucleus. The individual diformazan deposit showed dot-like and sometimes rod-like shapes. These organelles were difficult to count because of their great number and minute size. A pink reaction marking the mono-formazan of the tetrazolium salt was distributed throughout the cytoplasm. The distribution was equally widespread with a specially purified sample of tetranitro-BT. The different oxido-reductive enzymes showed an almost identical arrangement of the diformazan deposits in the epithelial cells. All enzymes, especially the diaphorases, showed marked activity.

There was decreased activity in the crypts and a weak overall stain throughout the lamina propria. Paneth cells stained positively.

MICROSOMAL ENZYMES Glucose-6-phosphatase and non-specific esterase (Fig. 7a) showed most activity in the apical part of the cell. The nuclear area appeared as a lightly stained zone separating apical and basal parts. In preparations for esterase the Golgi zone was occasionally recognizable as a narrow zone of reduced staining. No reaction was observed in the brush border. Neither enzyme showed much activity in the crypt cells. No glucose6-phosphatase activity was seen in the Paneth cells. Esterase activity, however, was found when the incubation time was extended.

Little activity was seen in the lamina propria. A stronger reaction appeared in the macrophages after longer incubation for esterase. This was E 600resistant, indicating the lysosomal nature of the enzyme.

GOLGI (LAMELlaR) ENZYME Thiamine pyrophosphatase was present only in small amounts, localized in the Golgi zone above the nucleus, in most of the crypt cells and in the lower villous epithelium. In contrast to the enzyme previously demonstrated 


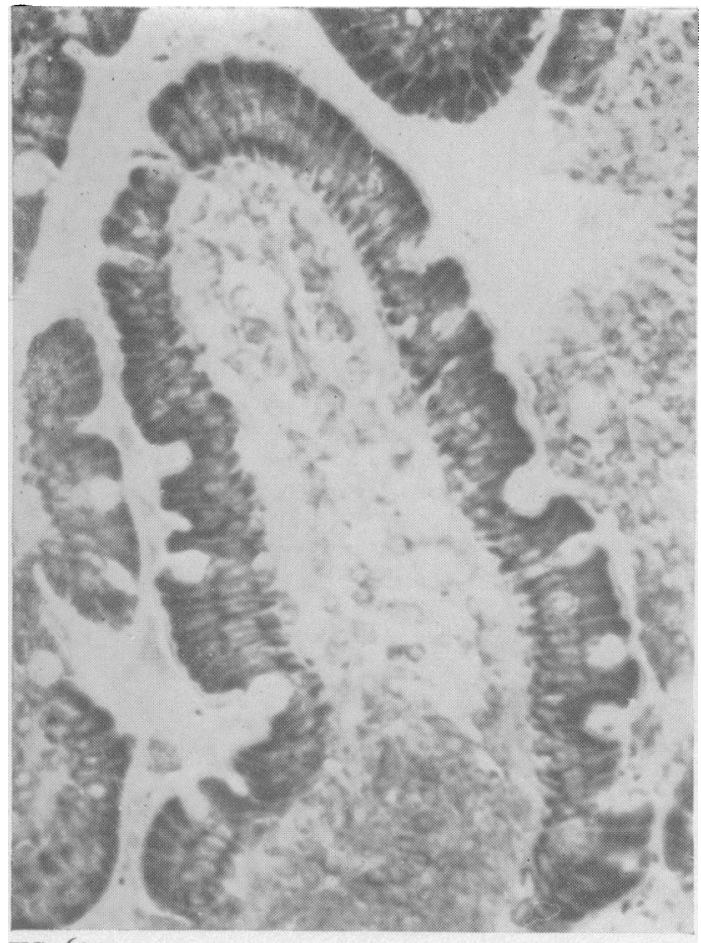

FIG. $6 \mathrm{a}$
FIG. 6a. Normal jejunum. Nicotine adenine dinucleotide diaphorase (Tetranitro BT); prefixed tissue. The bulk of the diformazan deposit is arranged in three zones; (1) between unstained brush border and weakly stained Golgi zone, (2) between Golgi area and upper rim of the nucleus, (3) between lower rim of the nucleus and lower basal cell border. $\times 310$.

FIG. 6b, c, and d. Jejunum. Succinic dehydrogenase. All three sections were incubated in the same medium, Fig $6 b$ showing a control, Fig. $6 c$ and $6 d$ sections from a patient with idiopathic steatorrhoea before and four weeks after treatment. The enzyme activity, markedly decreased before the gluten-free diet, is restored nearly to normal after treatment.

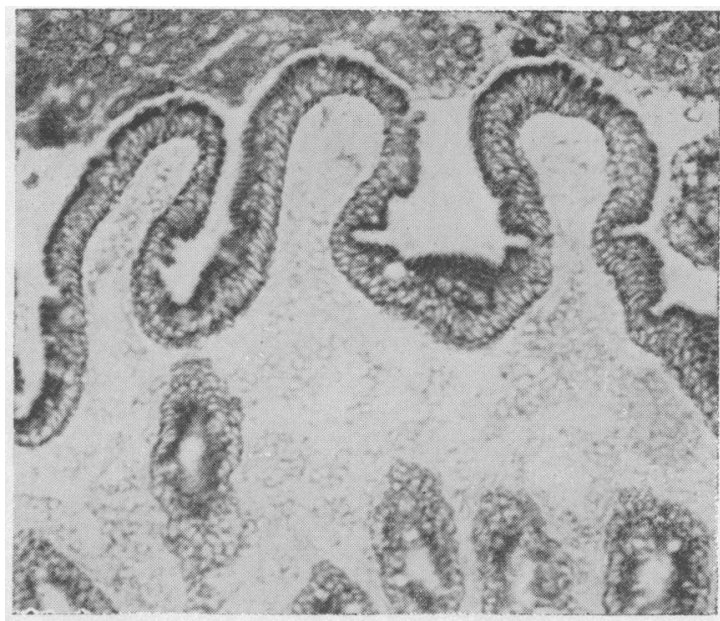

FIG. $6 b$

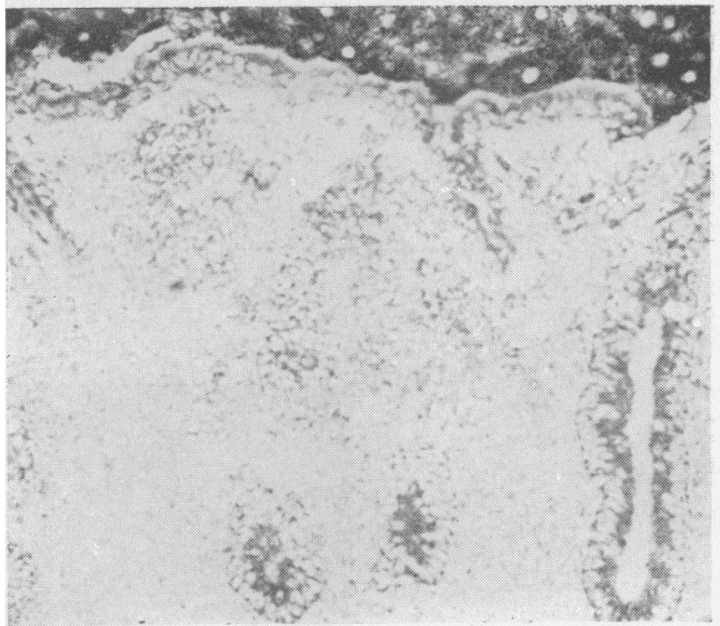

FIG. 6c

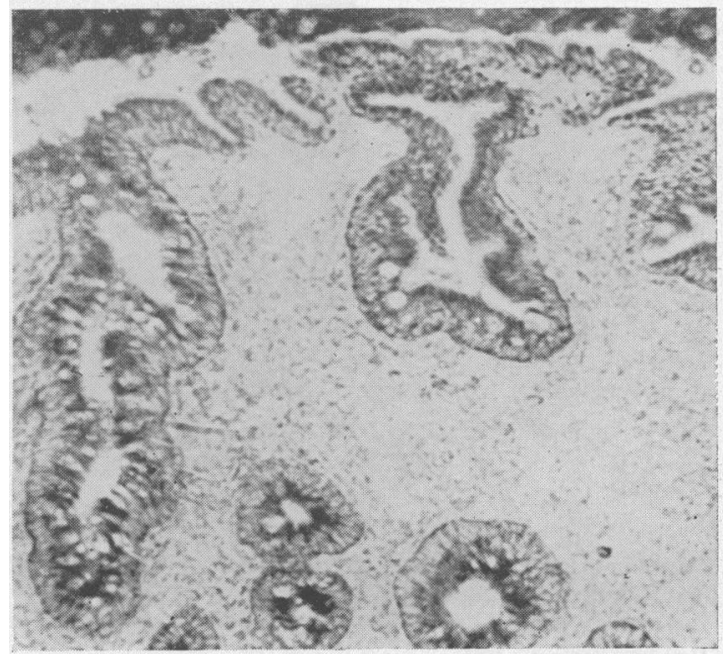

FIG. $6 \mathrm{~d}$ 


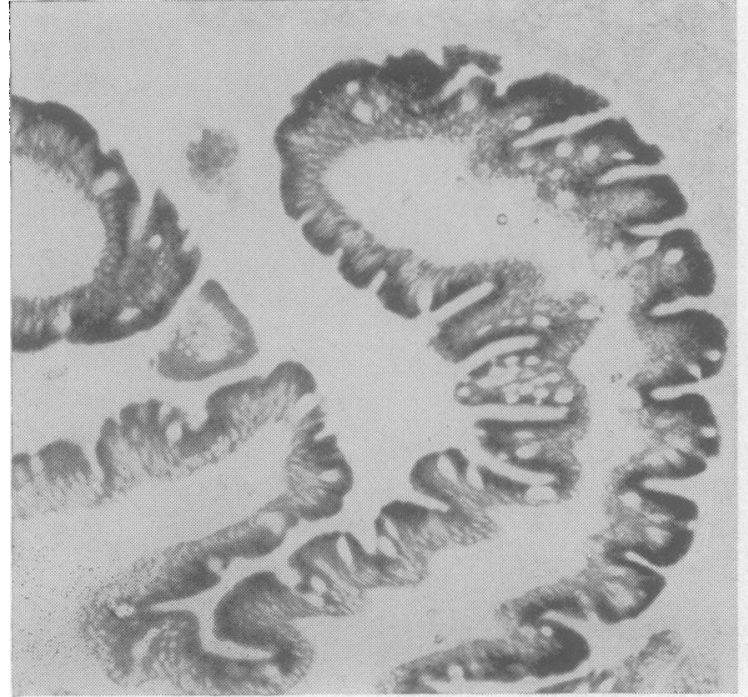

FIG. 7a.

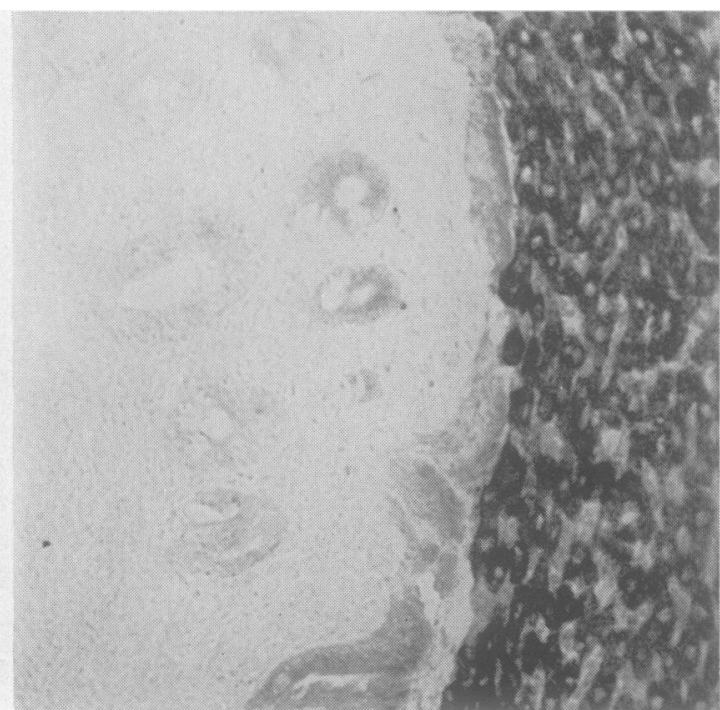

FIG. $7 \mathrm{~b}$.

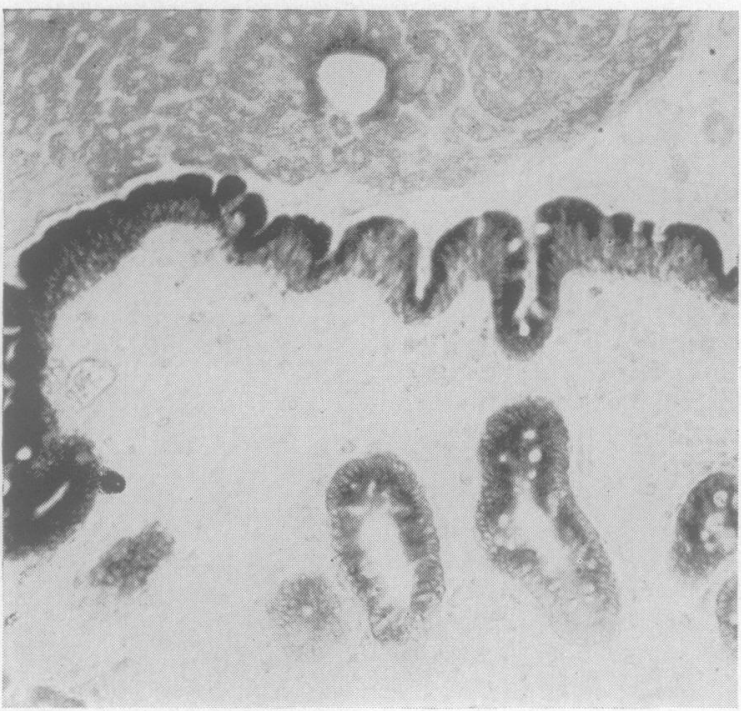

FIG. 7c.

FIG. 7a, b, and c. Jejunum. Non-specific esterase. Simultaneously incubated sections from a normal control (Fig. 7a) and a patient with idiopathic steatorrhoea before (Fig. 7 b) and after (Fig. 7c) gluten-free diet. The marked activity in the surface epithelium after treatment slightly exceeds that seen in the control, although surface cell and villous height are still reduced. $\times 160$. 


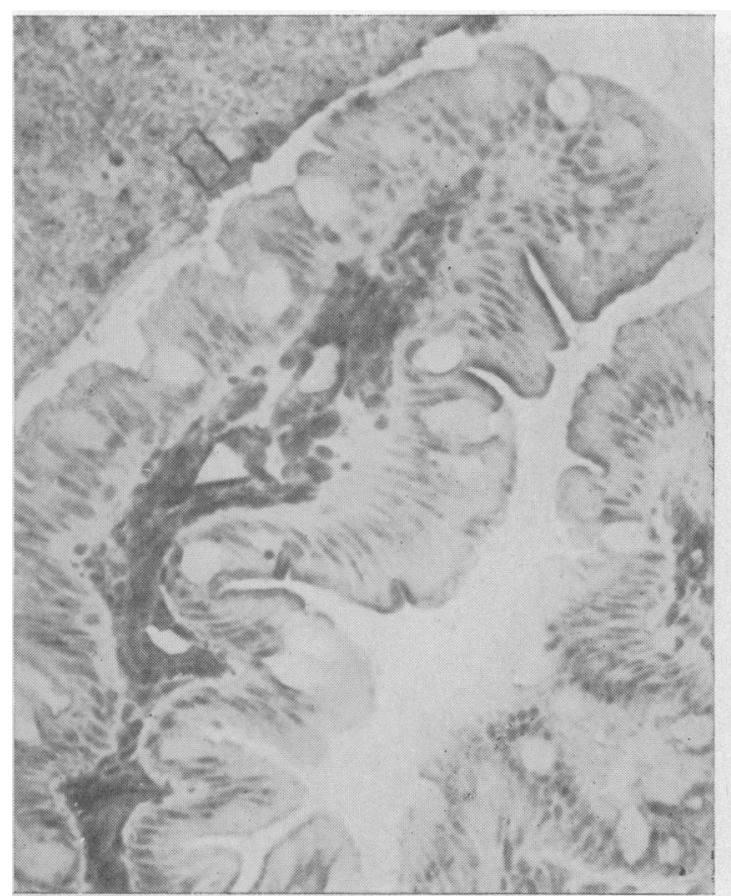

FIG. 8a.

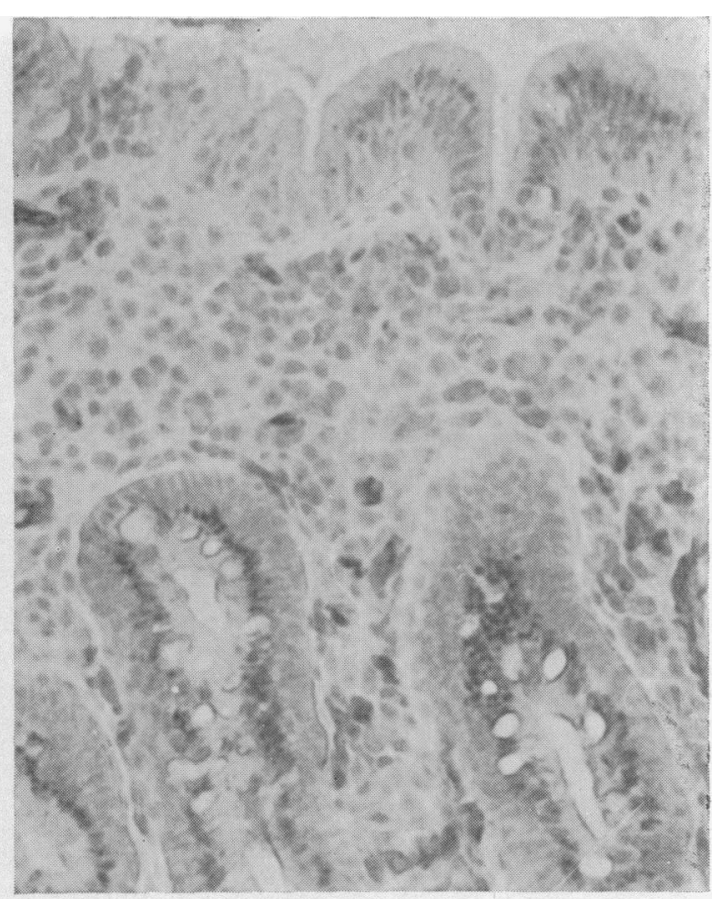

FIG. $8 \mathrm{~b}$.

FIG. 8a and b. Jejunum. Thiamine pyrophosphatase. No activity is seen in the villi of the control (Fig. 8a), incubated simultaneously with a section from a patient with untreated idiopathic steatorrhoea (Fig. 8b), which shows considerable activity in the crypt epithelium and $a$ weaker reaction in the surface epithelium marking the Golgi area. $\times 310$.

it was not found in the upper villous epithelium (Fig. 8a). No reaction was obtained in prefixed tissues but after post-fixation positive results were obtained and localization was reasonably distinct. Vessels and smooth muscle fibres of the lamina propria showed intense staining due to non-specific splitting. The specificity of the reaction in the Golgi zone can be assumed since it was resistant both to sodium fluoride and to L-phenyl-alanine.

\section{RESULTS IN CASES OF UNTREATED IDIOPATHIC STEATORRHOEA}

All enzymes demonstrated were decreased in biopsies from cases of untreated idiopathic steatorrhoea, but this reduction did not always occur simultaneously in the same patient. The three membrane enzymes studied were variably diminished as can be seen from Table I. Leucine aminopeptidase was the least affected. Complete loss of non-specific alkaline phosphatase (Fig. 1b) and ATP-ase in the surface epithelium was observed in one severely ill patient.

The most marked changes affected the lysosomal enzymes and consisted of a general decrease of activity in the surface epithelium. Formaldehyde- prefixed sections and those stained by the Barka and Anderson acid phosphatase technique showed that this reduction was associated with a decrease in the number and size of lysosomal bodies and in the staining intensity of the individual granules. The surface epithelium of severely ill patients showed virtually no granules (Fig. 3b). The cytoplasm showed generalized activity which increased progressively with reduction of lysosomal bodies. In less severely ill patients the normal arrangement was preserved and staining was only slightly less intense and more diffuse. In these cases a second zone of granules often appeared in the Golgi area. The upper part of the crypt, identical with the second zone of Padykula et al. (1961), stained more strongly than the surface epithelium and showed a positive Golgi zone (Fig. 3g). These changes in the surface epithelium were associated with an increase of activity in the macrophages of the lamina propria. When the epithelium was most severely affected, however, this activity receded. E 600-resistant esterase and glucuronidase activity remained consistently a little less marked than acid phosphatase activity. Activity in the Golgi zone was not observed. $\beta$-Glucosamini- 


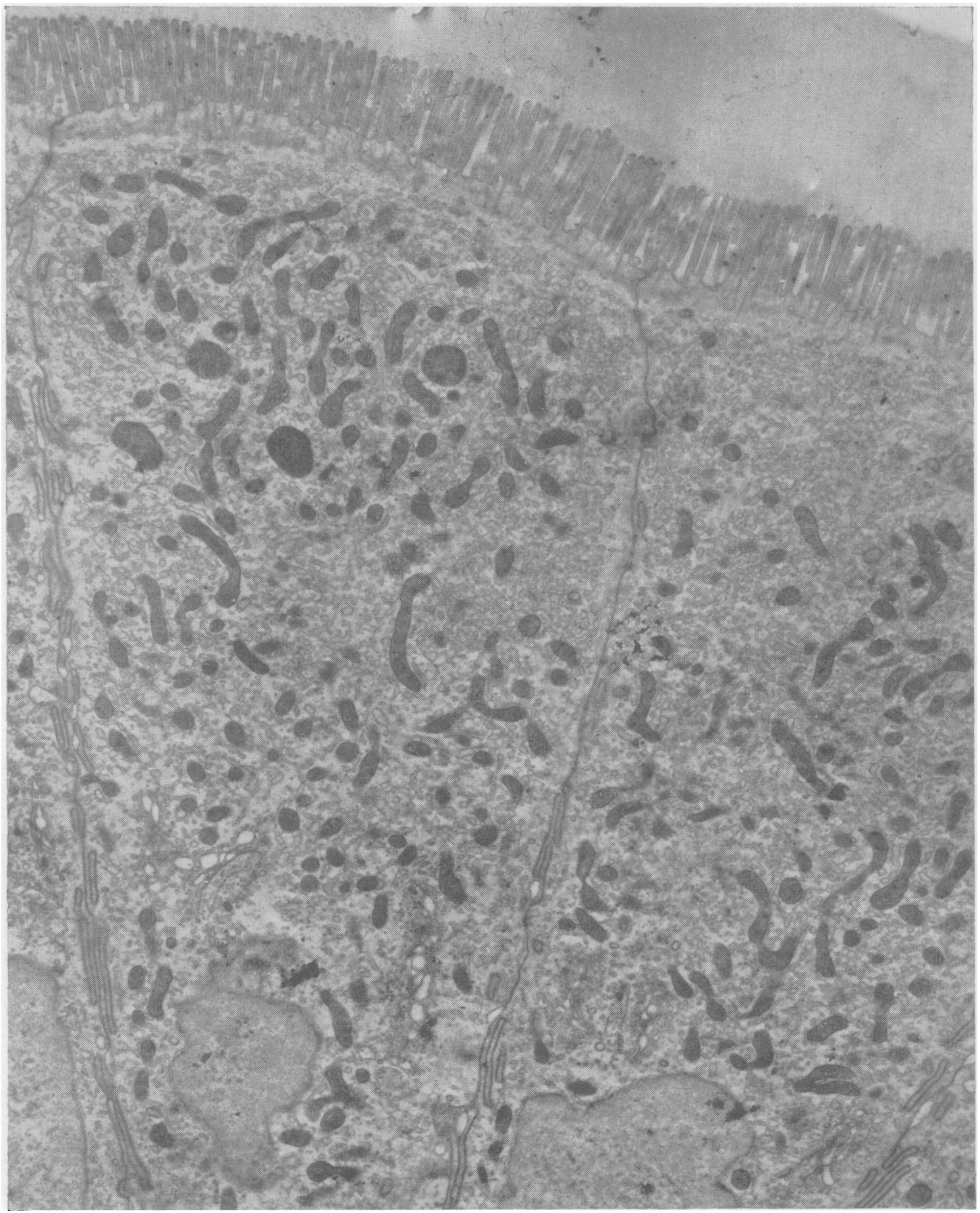

FIG. 9. Electron micrograph of a normal intestinal absorptive cell obtained from a jejunal biopsy of a healthy volunteer. The cellular arrangement of the fine structure corresponds to the cytoarchitecture as shown by light microscopy using histochemical enzyme techniques as 'marked' (Figs. 1a, 2a, 3a, 4a, 5a, 6a, 7a, 8b). × 8,260. 
TABLE I

SOME HISTOCHEMICAL ENZYME REACTIONS IN UNTREATED IDIOPATHIC STEATORRHOEA

\begin{tabular}{|c|c|c|c|c|c|c|c|c|c|c|c|c|c|}
\hline \multirow[t]{2}{*}{$\begin{array}{l}\text { Case } \\
\text { No. }\end{array}$} & \multicolumn{3}{|c|}{ Membrane Enzymes } & \multicolumn{3}{|c|}{ Lysosomal Enzymes } & \multicolumn{2}{|c|}{$\begin{array}{l}\text { Microsomal } \\
\text { Enzymes }\end{array}$} & \multicolumn{4}{|c|}{ Mitochondrial Enzymes } & \multirow{2}{*}{$\begin{array}{l}\text { Golgi Apparatus } \\
\text { Associated } \\
\text { Enzyme } \\
\text { Thiamine } \\
\text { Pyrophospha- } \\
\text { tase }\end{array}$} \\
\hline & $\begin{array}{l}\text { Alkaline } \\
\text { Phospha- } \\
\text { tase }\end{array}$ & $\begin{array}{l}\text { ATP- } \\
\text { ase }\end{array}$ & $\begin{array}{l}\text { LAP- } \\
\text { ase }\end{array}$ & $\begin{array}{l}\text { Acid } \\
\text { Phospha- } \\
\text { tase }\end{array}$ & $\begin{array}{l}\text { E600- } \\
\text { resistant } \\
\text { Esterase }\end{array}$ & $\begin{array}{l}\text { B-Gluco- } \\
\text { saminid- } \\
\text { ase }\end{array}$ & $\begin{array}{l}\text { Non- } \\
\text { specific } \\
\text { Esterase }\end{array}$ & $\begin{array}{l}\text { Glucose-6 } \\
\text { Phospha- } \\
\text { tase }\end{array}$ & $\begin{array}{l}\text { Succinic } \\
\text { Dehydro- } \\
\text { genase }\end{array}$ & $\begin{array}{l}\text { NAD H } \\
\text { Diaph- } \\
\text { orase }\end{array}$ & $\begin{array}{l}\text { NADP } H \\
\text { Diaph- } \\
\text { orase }\end{array}$ & $\begin{array}{l}\text { Mono- } \\
\text { amine } \\
\text { Oxidase }\end{array}$ & \\
\hline 1 & 1 & 1 & 1 & 1 & & 3 & 1 & 1 & 1 & 1 & 2 & 1 & \\
\hline 2 & 1 & 1 & 3 & 2 & & 3 & 1 & 1 & 1 & $\mathbf{1}$ & 2 & 2 & \\
\hline 3 & 1 & 2 & 1 & 1 & 1 & 1 & 1 & 1 & 1 & 1 & 1 & 1 & 4 \\
\hline 4 & 2 & 3 & 2 & 2 & & 1 & 2 & 3 & 3 & 3 & 3 & 3 & \\
\hline 5 & 3 & 3 & 2 & 1 & 1 & 2 & 2 & 2 & 2 & 2 & 3 & 3 & \\
\hline 6 & 0 & 0 & 1 & 1 & 1 & 1 & 1 & 1 & 1 & $\mathbf{1}$ & 1 & 1 & 4 \\
\hline 7 & 2 & 1 & 1 & 2 & & 1 & 3 & 3 & 3 & 2 & 3 & 3 & \\
\hline 8 & 2 & 1 & 1 & 1 & & 1 & 2 & 2 & 3 & 2 & 3 & 3 & \\
\hline 9 & 1 & 1 & 1 & 1 & & & 1 & 1 & 1 & 2 & 2 & 1 & 4 \\
\hline \multicolumn{7}{|c|}{$\begin{array}{l}0=\text { No activity } \\
1=\text { Marked reduced activity } \\
2=\text { Mildly reduced activity }\end{array}$} & \multicolumn{6}{|c|}{$\begin{array}{l}3=\text { Normal activity } \\
4=\text { Increased activity }\end{array}$} & \\
\hline
\end{tabular}

TABLE II

SOME HISTOCHEMICAL ENZYME REACTIONS IN A PATIENT WITH IDIOPATHIC STEATORRHOEA BEFORE AND DURING TREATMENT WITH A GLUTEN-FREE DIET

\begin{tabular}{|c|c|c|c|c|c|c|c|c|c|c|c|}
\hline \multirow{2}{*}{$\begin{array}{l}\text { Relationship } \\
\text { to Start of } \\
\text { Treatment }\end{array}$} & \multicolumn{3}{|c|}{ Membrane Enzymes } & \multicolumn{2}{|c|}{$\begin{array}{l}\text { Lysosomal } \\
\text { Enzymes }\end{array}$} & \multicolumn{2}{|c|}{$\begin{array}{l}\text { Microsomal } \\
\text { Enzymes }\end{array}$} & \multicolumn{4}{|c|}{ Mitochondrial Associated Enzymes } \\
\hline & $\begin{array}{l}\text { Alkaline } \\
\text { Phospha- } \\
\text { tase }\end{array}$ & ATP-ase & LAP-ase & $\begin{array}{l}\text { Acid } \\
\text { Phospha- } \\
\text { tase }\end{array}$ & $\begin{array}{l}\beta-\text {-Gluco- } \\
\text { saminid- } \\
\text { ase }\end{array}$ & $\begin{array}{l}\text { Non- } \\
\text { specific } \\
\text { Esterase }\end{array}$ & $\begin{array}{l}\text { Glucose-6 } \\
\text { Phospha- } \\
\text { tase }\end{array}$ & $\begin{array}{l}\text { Succinic } \\
\text { Dehydro- } \\
\text { genase }\end{array}$ & $\begin{array}{l}\text { NAD H- } \\
\text { Diaphor- } \\
\text { ase }\end{array}$ & $\begin{array}{l}\text { NADP H- } \\
\text { Diaphor- } \\
\text { ase }\end{array}$ & $\begin{array}{l}\text { Mono- } \\
\text { amine } \\
\text { Oxidase }\end{array}$ \\
\hline $\begin{array}{l}\text { Before } \\
\text { One week after } \\
\text { Two weeks after } \\
\text { Three weeks after } \\
\text { Four weeks after } \\
\text { Two months after } \\
\text { Three months after }\end{array}$ & $\begin{array}{l}0 \\
1 \\
1 \\
1-2 \\
3 \\
2 \\
2\end{array}$ & $\begin{array}{l}0 \\
1 \\
1 \\
1-2 \\
2 \\
2 \\
2\end{array}$ & $\begin{array}{l}0-1 \\
1 \\
1 \\
1-2 \\
2 \\
2 \\
2-3\end{array}$ & $\begin{array}{l}0-1 \\
1 \\
1-2 \\
2 \\
2 \\
2\end{array}$ & $\begin{array}{l}0-1 \\
1 \\
2 \\
2\end{array}$ & $\begin{array}{l}1 \\
1-2 \\
1-2 \\
1 \\
3 \\
3 \\
4\end{array}$ & $\begin{array}{l}0-1 \\
1 \\
1 \\
2-3 \\
3 \\
2 \\
3\end{array}$ & $\begin{array}{l}1-2 \\
2 \\
2 \\
2-3 \\
2 \\
2-3 \\
2\end{array}$ & $\begin{array}{l}2 \\
2 \\
2 \\
2-3 \\
2-3 \\
2-3 \\
3\end{array}$ & $\begin{array}{l}1 \\
2 \\
2 \\
2-3 \\
2-3 \\
3 \\
3\end{array}$ & $\begin{array}{l}0-1 \\
1-2 \\
2 \\
2-2 \\
2-3 \\
2 \\
2\end{array}$ \\
\hline $\begin{array}{l}0=\text { No activity } \\
1=\text { Markedly reduc }\end{array}$ & d activity & & & \multicolumn{4}{|c|}{$\begin{array}{l}2=\text { Mildly reduced activity } \\
3=\text { Normal activity }\end{array}$} & \multicolumn{4}{|c|}{$4=$ Increased activity } \\
\hline
\end{tabular}

dase was also reduced but its diffuse staining precluded accurate localization.

Oxido-reductive enzymes were reduced in proportion to the decrease in epithelial surface cell height in some cases, but in others there was clearly an independent reduction in staining intensity (Fig. $6 c)$. Of the microsomal enzymes, glucose-6-phosphatase seemed to be more sensitive than nonspecific esterase but both were severely affected (Fig. 7b).

The Golgi marker, thiamine pyrophosphatase, was investigated only in three patients with idiopathic steatorrhoea. In contrast to most of the enzymes, this showed increased activity. Although usually restricted to the epithelial cells of the crypts and lower portion of the villi in control subjects, it was present in the surface epithelium of patients with untreated idiopathic steatorrhoea (Fig. 8b; compare with Fig. 8a). The activity, however, remained weak and post-fixation of fresh sections was required for its demonstration.
RESULTS IN BIOPSIES FROM CASES TREATED WITH A GLUTEN-FREE DIET

A striking increase of activity was observed after treatment. This was associated with the gradual rearrangement of the cyto-architecture. The initial response occurred at one week and covered all the enzymes investigated.

The time relationships in one patient from whom seven biopsies were obtained are shown in Table II. The response of non-specific alkaline phosphatase (Figs. 1b, c and d), of ATP-ase, and of leucine aminopeptidase (Figs. $2 b$ and $2 c$ ) was dramatic and enzyme levels equal or almost equal to normal appeared within four weeks. The lysosomal marker, non-specific acid phosphatase, showed an increase of diffuse activity after one week and granular activity was recognizable after three weeks. A constant feature was the appearance of acid phosphatase in the Golgi zone, first observed in the third week and quite pronounced at three months. During 
further treatment acid phosphatase activity in this unusual site was absent only once, after withdrawal of gluten for 22 months (Figs. 3a, b, c, d, e, f) and this loss of activity was associated with complete return to normal of all the enzymes investigated. The greatest activity in the Golgi zone occurred in the patient who had been taking the gluten-free diet for 27 months (Fig. 3e). Macrophage activity in the lamina propria was often increased.

Lysosomal esterase levels of activity rose at four weeks. This was best seen after formaldehyde prefixation without E600 inhibition (Figs, 4a, b, c, d). Full restoration was seen only once, after 22 months on a gluten-free diet (Fig. 4a). A maximal response was observed with $\beta$-glucosaminidase after four months' treatment in one patient but this response was exceptional.

Oxido-reductive enzymes showed a rapid increase in activity. Normal levels were seen even earlier than with most of the hydrolytic enzymes (Figs. 6a, b, c).

No less striking was the rise in the level of nonspecific esterase activity which, in one patient, surpassed the normal range (Figs. $7 \mathrm{a}, \mathrm{b}, \mathrm{c}$ ). This occurred in spite of some persistent reduction in the height of surface cells. The other microsomal enzyme investigated, glucose-6-phosphatase, varied considerably in the timing of its response to treatment. Constant improvement, however, was observed after four weeks.

\section{DISCUSSION}

The histochemical pattern of the normal intestinal absorptive cell correlates well with the fine structural arrangement (Fig. 9) and is shown diagrammatically in Figure 10. It provides, simultaneously, information about the architecture of the cell and its metabolic activities, and both are fundamentally disturbed in idiopathic steatorrhoea.

The changes shown in the jejunum of untreated patients in this study are essentially in agreement with previous findings (Padykula et al., 1961; Padykula, 1962) but the accurate localization of lysosomal enzymes has not been fully studied hitherto (Spiro et al., 1964; Fric and Lojda, 1964). A general decrease of enzymatic activity was associated with reduction in height of the epithelial surface cells, distortion of the nuclei, and the transformation of the whole mucosa as described by Padykula and her colleagues (1961). Their three zones were seen in jejunum of some but not all patients in the present study. There was not always a good relationship between the severity of the histochemical lesion and the clinical picture but this is to be expected since the functional defect depends not only on the severity of the proximal lesion but also on its extent through-

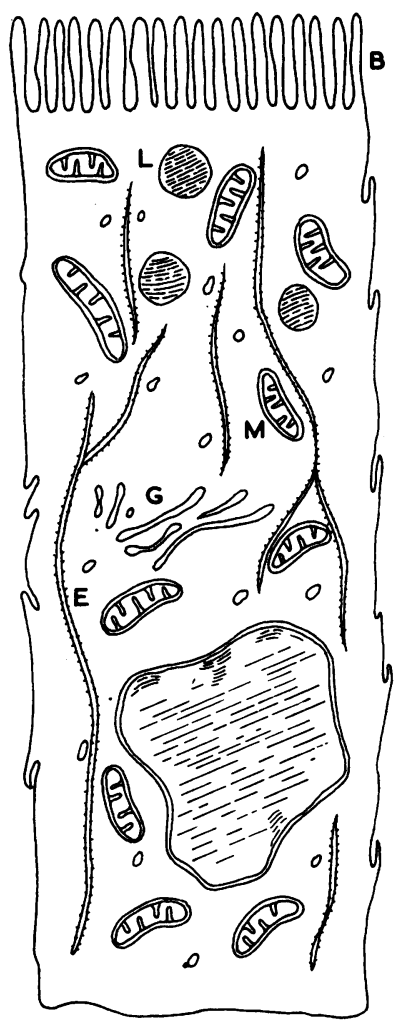

FIG. 10. Diagrammatic representation of a normal intestinal absorptive cell to show the structures localized by histochemical enzyme techniques. $B$ Brush border (alkaline phosphatase, ATP-ase, BAP-ase). $L$ Lysosomes (acid phosphatase, $\beta$ glucuronidase, E600resistant esterase, $\beta$-glucosaminidase). M Mitochondria (succinic dehydrogenase, monoamine oxidase (NADHdiaphorase)). G Golgi apparatus (thiamine pyrophosphatase).

E Endoplasmic reticulum (unspecific esterase, glucose-6phosphatase).

out the small intestine (MacDonald, Brandborg, Flick, Trier, and Rubin, 1964). It should be emphasized that all enzymes were affected, including nonspecific alkaline phosphatase, repeatedly found to be unchanged in previous studies (Padykula et al., 1961; Spiro et al., 1964; Samloff et al., 1965); however, not all of them are necessarily decreased in the same patient. Thus a normal alkaline phosphatase level was seen in the jejunum of two patients associated in one instance with severe reduction in other enzyme systems and a marked decrease in surface cell height. This emphasizes the great variability of the changes in this disease, reflected in the different reported series.

Attention is also drawn to a possibly increased rate of production of some enzymes in spite of the reduction in the activity demonstrated. Three observations support this suggestion. First, a normal alkaline phosphatase level could not readily be maintained in the presence of severe morphological abnormalities unless there was some compensating factor such as increased enzyme production. This is supported by electron-microscopical observations which show that the most constant mucosal abnormality in this disease is a damaged brush border. 
A second, more fully documented feature, is the increased production of non-specific acid phosphatase. It has been suggested that lysosomes may originate in the Golgi apparatus (Novikoff, Goldfischer, Essner, and Iaciofano, 1961; Becker and Sandbank, 1964). Non-specific acid phosphatase is, however, rarely if ever seen in the Golgi zone of the normal intestinal epithelial cell, providing there is no overincubation. The marked activity often found in untreated idiopathic steatorrhoea and regularly seen during treatment suggests greatly increased enzyme production. In the normal small intestine the origin of the lysosomes from the Golgi apparatus is not demonstrable, probably because the production rate of lysosomes is too low (Riecken and Pearse, 1965). In this study, the enzyme activity in the Golgi apparatus was abolished by sodium fluoride, thus excluding interference by alkaline phosphatase.

Thirdly, the appearance of thiamine pyrophosphatase in the surface epithelium and its increased activity in the crypt cells show enhanced production of this enzyme also (Fig. 8a, b). This enhanced enzyme production suggests a disturbance of the normal dynamic equilibrium between the anabolic and catabolic activities of the cell. A similar compensatory response to damage is suggested by the appearance of basophilia in the surface epithelium and the increased mitotic counts in the crypt cells (Padykula et al., 1961).

It has been shown that the primitive absorptive cell originates in the crypt and migrates towards the tip of the villus (Leblond and Stevens, 1948). During its passage it is differentiated into the definitive absorptive cell. The association of basophilia and TPP-ase in the normal crypt cells may suggest a relationship to the formation of ribonucleic acid. It has been shown by electron microscopy (Rubin, Brandborg, Flick, MacDonald, Parkins, Parmentier, Phelps, Sribhibhadh, and Trier, 1962) that the normal crypt cell contains a greater amount of free ribosomes than the villous epithelium. In idiopathic steatorrhoea, however, ribosomes in the surface epithelial cells are increased. The appearance of the TPP-ase activity in the same cells supports its functional relationship and emphasizes the part it may play in the enhanced synthesis of protein. All these changes confirm that the surface epithelium is severely damaged and unable to maintain its normal structure and function in spite of what appear to be compensatory mechanisms. It seems likely that the primary defect is due to some agent which damages the surface cells of the mucosa and that the increased mitotic rate and enzyme activity both reflect an attempt to compensate for a loss of surface cells by an increased production of cells in the crypts.
The special role of gluten in the development of this disease has been established (Dicke, 1950), although the mechanism of the pathogenesis is not understood. The histochemical response to gluten withdrawal is no less striking than the clinical improvement and, except for glucose-6-phosphatase, began within a week in all enzymes studied. There is a good correlation between enzymatic recovery and increase of surface cell height. The gross mucosal appearance, as shown by the dissecting microscope, changes more slowly. The histochemical findings of Spiro et al. (1964) on repeat biopsies from five patients over a period of one to nine months after the start of a gluten-free diet showed corresponding results in most cases. The results of the studies of lysosomal enzymes suggest a possible fundamental role of the lysosomes in the development of the lesions of the surface cells.

The high sensitivity of the lysosomal membrane to a variety of forms of damage has been shown by biochemical and histochemical investigations (Gianotto and de Duve, 1955; Wattiaux and de Duve, 1956). The increased 'free' lysosomal activity in cirrhosis and hepatitis (Pagliario, Giglio, Le Moli, Catania, and Citarrella, 1964) and in hypervitaminosis A (Weissmann and Thomas, 1963) provide good examples.

The changes in lysosomal enzymes demonstrated in idiopathic steatorrhoea similarly reflect widespread dispersal of hydrolytic activity, although the total amount is usually decreased. Enhanced lysosomal regeneration is not only inhibited but leads to a vicious circle unless the toxic agent is removed; the stronger the compensatory response, the more the autodigestive activity in the cell. Reduced cell height, decreased enzyme activity, and transformation of the mucosa seem to be the consequence. The cells in the upper part of the elongated crypt, identical with the middle zone of Padykula et al. (1961) and Padykula (1962), probably represent a transitional zone, as they suggested. While the surface epithelium is engaged in full enzyme production and, therefore, exposed to the strongest damage, the enzymes of the middle zone and crypt epithelium are not usually active enough to produce major changes. The appearance of acid phosphatase in the Golgi apparatus in the cells of this 'transitional zone' (Fig. 3g), suggests, however, that no fundamental differences exist in the mechanism of damage in the three zones. The different histochemical appearances seem to reflect change due to the same toxic agent.

In conclusion, the evidence presented in this paper suggests that the histochemical appearance of the jejunal mucosa in idiopathic steatorrhoea is the result of two opposing forces, the enhanced anabolic and catabolic activities of the cell. The variable pre- 
ponderance of the one or the other may explain the great variation from patient to patient and the occasional merging of the transitional zone with the upper, severely damaged surface epithelium.

We gratefully acknowledge the technical assistance of Mr. Ralph Nunn with the electron microscopy and Mr. John Bancroft with the histochemistry of some of the biopsy specimens.

\section{REFERENCES}

Barka, T., and Anderson, P. J. (1962). Histochemical methods for acid phosphatase using hezazonium pararosanilin as coupler. J. Histochem. Cytochem., 10, 741-753.

Barrnett, R. J. (1962). The fine structural localization of acetylcholinesterase at the myoneural junction. J. Cell Biol., 12, 247-262.

Becker, N. H., and Sandbank, U. (1964). The neuronal Golgi apparatus and lysosomes in neonatal rats. J. Histochem. Cytochem., $12,483-485$.

Brackenbury, W., and Stewart, J. S. (1963). Macroscopic appearances of mucosal biopsies from the small intestine. Med. biol. Ill., 13, $220-227$.

Burstone, M. S. (1958). Histochemical comparison of naphthol-ASphosphates for the demonstration of phosphatases. J. nat. Cancer Inst., 20, 601-616.

Crosby, W. H., and Kugler, H. W. (1957). Intraluminal biopsy of the small intestine: the intestinal biopsy capsule. Amer. J. dig., Dis., 2, 236-241.

Dicke, W. K. (1950). Coeliac disease. Investigation of the harmful effects of certain types of cereal on patients with coeliac disease. Thesis, Utrecht.

Fric, P., and Lojda, Z. (1964). Enzymes of the human jejunal mucosa. Acta gastro-ent. belg., 27, 526-530.

Gianotto, R., and Duve, C. de. (1955). Tissue fractionation studies. 4. Comparative study of the binding of acid phosphatase, $\beta$-glucuronidase and cathepsin by rat-liver particles. Biochem. J., 59, 433-438.

Glenner, G. G., Burtner, H. J., and Brown, G. W., Jr. (1957). The histochemical demonstration of monoamine oxidase activity by tetrazolium salts. J. Histochem. Cytochem., 5, 591-600.

Gomori, G. (1952). Microscopic Histochemistry; Principles and Practice, pp. 189-194. University of Chicago Press, Chicago.

Hess, R., and Pearse, A. G. E. (1958). The histochemistry of indoxylesterase of rat kidney with special reference to its cathepsin-like activity. Brit. J. exp. Path., 39, 292-299.

Holt, S. J. (1958). Indigogenic staining methods for esterases. In General Cytochemical Methods, edited by J. F. Danielli, vol. I, pp. 375-398, Academic Press Inc., New York.

Holmes, R., Hourihane, D. O'B., and Booth, C. C. (1961). Dissectingmicroscope appearances of jejunal biopsy specimens from patients with idiopathic steatorrhoea. Lancet, 1, 81-83.

Leblond, C. P., and Stevens, C. E. (1948). The constant renewal of the intestinal epithelium in the albino rat. Anat. Rec., 100, 357377.

MacDonald, W. C., Brandborg, L. L., Flick, A. L., Trier, J. S., and Rubin, C. E. (1964). Studies of celiac sprue. IV. The response of the whole length of the small bowel to a gluten-free diet. Gastroenterology, 47, 573-589.

Nachlas, M. M., Crawford, D. T., and Seligman, A. M. (1957). The histochemical demonstration of leucine aminopeptidase. J. Histochem. Cytochem., 5, 264-278.

—, Tsou, K. C., Souza, E. de, Cheng, C. S., and Seligman, A. M. (1957). Cytochemical demonstration of succinic dehydrogenase by the use of a new p-nitrophenyl substituted ditetrazole. Ibid., 5, 420-436.
Novikoff, A. B., Goldfischer, S., Essner, E., and Iaciofano, P. (1961) The relations between acid phosphatase-rich lysosomes and the Golgi apparatus. Ibid., 9, 630 .

Novikoff, A. B., and Goldfischer, S. (1961). Nucleoside-diphosphatase activity in the Golgi apparatus and its usefulness for cytological studies. Proc. nat. Acad. Sci. (Wash.), 47, 802-810.

Padykula, H. A. (1962). Recent functional interpretations of intestinal morphology. Fed. Proc., 21, 873-879.

Padykula, H. A., Strauss, E. W., Ladman, A. J., and Gardner, F. H. (1961). A morphologic and histochemical analysis of the human jejunal epithelium in non-tropical sprue. Gastroenterology, 40, 735-765.

Pagliaro, L., Giglio, F., Le Moli, S., Catania, A., and Citarrella, P. (1964). $\beta$-glucuronidase and acid phosphatase activities of lysosomal preparations from human liver tissue obtained by needle biopsy from subjects with acute hepatitis and cirrhosis. J. Lab. clin. Med., 63, 977-985.

Plosscowe, R. P., Berg, G. G., and Segal, H. L. (1963). Enzyme histochemical studies of human gastric and jejunal biopsy specimens in normal and disease states. Amer. J. dig. Dis., 8, 311-318.

Pugh, D., and Walker, P. G. (1961). Histochemical localization of $\beta$-glucuronidase and $\mathrm{N}$-acetyl- $\beta$-glucosaminidase. $J$. Histochem. Cytochem., 9, 105-106.

Riecken, E. O., and Pearse, A. G. E. (1966). Demonstration of acid phosphatase activity in the Golgi apparatus of the jejunal epithelium cell in patients with idiopathic steatorrhoea. Histochemie. In press.

Rubin, C. E., Brandborg, L. L., Flick, A. L., MacDonald, W. C., Parkins, R. A., Parmentier, C. M., Phelps, P., Sribhibhadh, S., and Trier, J. S. (1962). Biopsy studies on the pathogenesis of coeliac sprue. In Intestinal Biopsy, a Ciba Foundation Study Group No. 14, pp. 67-83. Churchill, London.

Sabatini, D. D., Bensch, K., and Barrnett, R. J. (1963). Cytochemistry and electron microscopy. The preservation of cellular ultrastructure and enzymatic activity by aldehyde fixation. $J$. Cell Biol., 17, 19-58.

Scarpelli, D. G., Hess, R., and Pearse, A. G. E. (1958). The cytochemical localization of oxidative enzymes. I. Diphosphopyridine nucleotide diaphorase and triphosphopyridine nucleotide diaphorase. J. biophys. biochem. Cytol., 4, 747-752.

Samloff, I. M., Davis, J. S., and Schenk, E. A. (1965). A clinical and histochemical study of celiac disease before and during a glutenfree diet. Gastroenterology, 48, 155-172.

Shiner, M., and Doniach, I. (1960). Histopathologic studies in steatorrhea. Ibid., 38, 419-440.

Spiro, H. M., Filipe, M. I., Stewart, J. S., Booth, C. C., and Pearse, A. G. E. (1964). Functional histochemistry of the small bowel mucosa in malabsorption syndromes. Gut, 5, 145-154.

Sylven, B., and Bois-Svensson, J. (1964). Studies on the histochemical 'leucine aminopeptidase' reaction. IV. Chemical and histochemical characterization of the intracellular and stromal L. N. A. reactions in solid tumour transplants. Histochemie, 4,135-149.

Wachstein, M., and Meisel, E. (1956). On the histochemical demonstration of glucose-6-phosphatase. J. Histochem. Cytochem., 4, 592 .

- (1957). Histochemistry of hepatic phosphatases at a physiologic pH. Amer. J. clin. Path., 27, 13-23.

Wächtler, K., and Pearse, A. G. E. (1966). The histochemical demonstration of five lysosomal enzymes in the pars distalis of the amphibian pituitary. Zschr. Zellforsch. In the press.

Wattiaux, R., and Duve, C. de (1956). Tissue fractionation studies. 7. Release of bound hydrolases by means of Triton X-100 Biochem. J., 63, 606-608.

Weissmann, G., and Thomas, L. (1963). Studies on lysosomes. II. The effect of cortisone on the release of acid hydrolases from a large granule fraction of rabbit liver induced by an excess of vitamin A. J. clin. Invest., 42, 661-669. 